\section{A Micropropagation System for Hazelnuts (Corylus Species)}

\author{
Xiaoling Yu \\ Department of Horticulture, Oregon State University, Corvallis, OR 97331
}

Barbara M. Reed ${ }^{1}$

U.S. Department of Agriculture, Agricultural Research Service, National Clonal Germplasm Repository, 33447 Peoria Road, Corvallis, OR 97333-2521

Additional index words. in vitro culture, culture establishment, ex vitro rooting, rootstocks, cultivars, Corylus avellana, Corylus colurna

\begin{abstract}
A micropropagation system was developed for hazelnut cultivars. Grafted greenhouse-grown plants produced many more viable explants than upper branches of mature field-grown trees. Shoots from grafted greenhouse-grown plants collected March through July and suckers of mature field-grown trees collected in July produced the most growing explants $(46 \%$ to $80 \%$ ). Three- to five-fold multiplication was obtained after 4 weeks of culture on NCGR-COR medium supplemented with $6.7 \mu_{\mathrm{M}}$ BA and $0.04 \mu_{\mathrm{M}}$ IBA. Roots were produced on $64 \%$ to $100 \%$ of shoots grown on half-strength NCGR-COR mineral salts and $4.9 \mu_{\mathrm{M}}$ IBA for 4 weeks. Ex vitro rooting by a brief dip in 1 or 5 mM IBA was equally successful. Transplant survival was $78 \%$ to $100 \%$. Chemical names used: $N^{6}$. benzyladenine (BA); indole-3-butyric acid (IBA).
\end{abstract}

Researchers have demonstrated hazelnut micropropagation with seedling and juvenile materials, but adult tree culture has been impeded by problems with microbial contamination and low initiation and multiplication rates (Bassil et al., 1992; Diaz-Sala et al., 1990; Messeguer and Mele, 1987; Perez et al., 1987). Recent improvements in hazelnut micropropagation have provided increased opportunities for micropropagation of named cultivars (Bassil et al., 1992; Diaz-Sala et al., 1990; Yu and Reed, 1993). Micropropagation for fast dissemination of new nut and rootstock cultivars could be an alternative to traditional propagation by field layering.

Explant juvenility is one of the most important factors affecting the in vitro response of many woody plants. Juvenile materials are generally easier to propagate than mature materials. Therefore, selecting the most juvenile tissues within a tree or rejuvenating donor tree parts by special treatments before excising explants has been adopted for woody plants

\footnotetext{
Received for publication 25 July 1994. Accepted for publication 3 Oct. 1994. This paper is a portion of a dissertation submitted by Xiaoling Yu in fulfillment of the $\mathrm{PhD}$ requirements of Oregon State Univ. (OSU), Corvallis. This study was supported by USDA-ARS CRIS 5358-21000-014-00D and the Oregon Filbert Commission. We gratefully acknowledge the assistance of Joe Snead and Jim Chandler in grafting and the statistical assistance of Cliff Periera. The use of trade names in this publication does not imply endorsement by the U.S. Dept. of Agriculture or OSU. The cost of publishing this paper was defrayed in part by the payment of page charges. Under postal regulations, this paper therefore must be hereby marked advertisement solely to indicate this fact.

${ }^{1}$ To whom reprint requests should be addressed.
}

(Bonga, 1987). Root suckers and stump sprouts are more juvenile than other branches and thus provide a good choice for explants (Thorpe and Harry, 1990). Rejuvenation or reinvigoration techniques include repeatedly spraying branches intended for explant with cytokinin (commonly BA) (Abo El-Nil, 1982), serial grafting (Franclet et al., 1987), serial rooting of mature cuttings, and repeated subculture of shoot apices in cytokinin-containing medium (Thorpe and Harry, 1990).

Researchers attempting hazelnut micropropagation have used rejuvenated or reinvigorated adult tissues. Messeguer and Mele (1987) obtained growth from $<50 \%$ of explants taken from rooted branches of mature 'Gironell' plants (Corylus avellana L.) grown for 2 years in a greenhouse. Perez et al. (1987) obtained $70 \%$ active growth in vitro of lateral buds taken from the vegetative shoots of 12month-old, greenhouse-grown cuttings of 'Negret' . Diaz-Sala et al. (1990) obtained 80\% bud outgrowth of explants from forced shoots of cold-stored, field-grown, mature branches of 'Tonda Gentile delle Langhe'.

The season in which explants are collected also can influence in vitro response. For example, explants collected in the autumn from greenhouse-grown 'Negret' plants produced $63 \%$ growing shoots compared to $38 \%$ and $10 \%$ from spring- and summer-collected explants, respectively (Messeguer and Mele, 1983).

Earlier, we developed an improved medium for optimum multiplication of hazelnut cultivars (Yu and Reed, 1993). We found there was still a need to improve some steps in initiating and culturing mature plant material and ultimately returning rooted shoots to the soil. In this study, our objective was to develop a micropropagation system for hazelnut rootstock and nut cultivars.
We used 6- to 10-year-old 'Barcelona', 'Gasaway', 'Willamette', 'Dundee', and 'Newberg' hazelnut (Corylus avellana) trees as explant sources. 'Barcelona' is the leading cultivar in Oregon. 'Gasaway' is a pollinizer and highly resistant to eastern filbert blight (Mehlenbacheretal., 1991b), and 'Willamette' is a new cultivar for the blanched kernel market (Mehlenbacher et al., 1991a). 'Newberg' (USOR 7-71) and 'Dundee' (USOR 15-71) are two new nonsuckering rootstocks, selected from open-pollinated C. colurna L. seed. Based on morphological characteristics, 'Newberg' and 'Dundee' appear to be Corylus interspecific hybrids (Lagerstedt, 1990, 1993). 'Barcelona' [National Clonal Germplasm Repository (NCGR) accession \#36], 'Gasaway' (NCGR accession \#54), 'Dundee' (NCGR accession \#165), and 'Newberg' (NCGR accession \#168) were taken from collections at the NCGR, Corvallis, Ore., and 'Willamette' was collected from the Oregon State Univ., Dept. of Horticulture Research Farm, Corvallis.

Culture establishment. 'Barcelona' and 'Gasaway' explants were collected from three sources at similar development stages: 1) grafted greenhouse-grown plants (Dormant branches were collected from field-grown trees in December, stored at $4 \mathrm{C}$, and grafted onto 'Barcelona' seedling rootstocks in a greenhouse in January using whip-and-tongue grafting; grafted plants grew in the greenhouse for the rest of the growing season, and explants were collected in March, May, and July.); 2) upper branches of field-grown trees in May, June, and August; 3) suckers of field-grown trees in June, July, and September.

Forced outgrowth of field-grown 'Gasaway' branches also was tested. Fieldgrown branches were collected in April, washed with tap water, disinfested for $10 \mathrm{~min}$ with a $15 \%$ bleach (containing $5.25 \%$ sodium hypochlorite) (Clorox, Oakland, Calif.) solution with a few drops of Tween 20 (polyoxyethylene sorbitan monolaurate) (Sigma, St. Louis), and rinsed with tap water. After the bases were recut, they were immersed in forcing solution [9 $\mathrm{g}$ Floralife/liter (Floralife, Burr Ridge, Ill.)] at $23 \pm 2 \mathrm{C}$ in the laboratory. The basal ends of branches were pruned off, and the solutions were replaced weekly. New shoots were collected after 3 to 4 weeks (in May).

Three new cultivars ('Willamette', 'Dundee', and 'Newberg') were used to determine whether varied genotypes of grafted greenhouse-grown plants established well in culture. Explants were taken from grafted greenhouse-grown plants (as previously described) in March, May, and July.

Shoots were collected, washed with soapy water, and rinsed with tap water after the leaves were trimmed off. Then, shoots were cut into single-node segments and surface disinfested for $10 \mathrm{~min}$ in a $15 \%$ bleach solution with 1 drop of Tween 20 per $80 \mathrm{ml}$ of bleach solution, followed by two rinses with sterile deionized water. Only lateral-bud segments with a single node each were used for most 
experiments. In March, shoot tips from grafted greenhouse-grown plants of 'Barcelona', 'Gasaway', and 'Willamette' also were used to compare explants from apical shoot tips and nodal segments. All explants were recut into segments 10 to $15 \mathrm{~cm}$ long and placed individually into $16 \times 100$-mm culture tubes containing $5 \mathrm{ml}$ culture medium. Fifteen explants were used per treatment.

Plant material was cultured on NCGRCOR medium, a modified DKW medium (Driver and Kuniyuki, 1984), altered by substituting $30 \mathrm{~g}$ glucose/liter for sucrose, $200 \mathrm{mg}$ Sequestrene 138 Fe/liter (Ciba Geigy, Greensboro, N.C.) for FeEDTA, and $5 \mathrm{~g}$ agar/liter (Difco Bitek agar, Detroit, Mich.) for Gelrite. For culture establishment, $22.2 \mu \mathrm{M}$ BA and $0.04 \mu \mathrm{MIAA}$ were added. Cultures were placed in a growth room at $25 \mathrm{C}$ with a $16-\mathrm{h}, 25-$ $\mu \mathrm{mol} \cdot \mathrm{m}^{-2} \cdot \mathrm{s}^{-1}$ photoperiod via cool-white fluorescent illumination. After 4 weeks in culture, data on the number of explants contaminated, browned, and proliferated (budbreak and elongation) were collected, and new shoots were subcultured.

To reduce tissue browning, explants from upper branches and suckers of field-grown trees were treated in one of three ways: 1) immersed in a solution (per liter of water) of 1 $\mathrm{g}$ ascorbic acid for $2 \mathrm{~h}, 24 \mathrm{mg}$ cysteine for $1 \mathrm{~h}$, or $1 \mathrm{~g}$ 8-hydroxy-quinoline hemisulfate salt (8-HQS) (Sigma) for $8 \mathrm{~h}$ following cleaning with soapy water but before surface disinfestation; 2) immersed in a solution (per liter of water) of $2 \mathrm{~g}$ diethyldithiocarbamic acid, sodium salt (DIECA) solution (filter-sterilized) for $2 \mathrm{~h}$, or $200 \mathrm{mg} \mathrm{K}_{2} \mathrm{~S}_{2} \mathrm{O}_{7}$ (filter-sterilized) for $1 \mathrm{~min}$ immediately after surface disinfestation; or 3 ) covered with $0.1 \%$ solution of 8 HQS (filter-sterilized) applied to the top of agar medium for the first 6,12 , or $24 \mathrm{~h}$ of culture on medium and then transferred onto fresh culture medium (Laimer da Camara Machado et al., 1991).

To determine the relationship between phenolic content and tissue browning, shoot tips and nodal segments from grafted greenhouse-grown plants and upper branches and suckers of field-grown 'Gasaway' and 'Barcelona' trees were used in June to determine phenolic concentration using methods described by Oydvin and Richardson (1987).

Shoot multiplication. Shoots from established 'Willamette', 'Dundee', and 'Newberg' cultures were cut into nodal segments and shoot tips, grown in Magenta GA7 boxes (Magenta, Chicago) containing $40 \mathrm{ml}$ NCGRCOR medium supplemented with $6.7 \mu \mathrm{M}$ BA and $0.04 \mu \mathrm{M}$ IBA, and subcultured at 4-week intervals. Nodal explants taken from this material were used to determine the optimum growth regulator combination for shoot multiplication. Combinations tested were as follows (in $\mu \mathrm{M}$ ): 6.7 BA, 6.7 BA + 0.04 IBA, 22.2 $\mathrm{BA}$, and 8.9 BA + 4.9 N6-(2-isopentenyl) adenine (2iP). Twenty-four explants (two replications of 12 per treatment) for each genotype were used in a randomized completeblock design, and the experiment was performed twice (48 explants per treatment per genotype). Number of shoots produced per explant and average shoot length were recorded after 4 weeks of culture.

Root induction and acclimatization. Root induction first was tested in vitro. Shoots (20 to $30 \mathrm{~mm}$ long) formed on multiplication medium were transferred to Magenta GA7 boxes containing NCGR-COR medium at half of the normal concentration of mineral salts with 4.9 $\mu \mathrm{M}$ IBA for 4 weeks. One day before removing plantlets from the culture box, the lid was loosened. The plants wilted but recovered after transplanting. Rooted and nonrooted shoots were transplanted into $200-\mathrm{ml}$ plastic pots containing a mix of 1 vermiculite : 1 perlite $(\mathrm{v} / \mathrm{v})$, placed in a mist bed for 2 to 3 weeks, then moved to the greenhouse bench for another 2 weeks, and finally transplanted to $700-\mathrm{ml}$ pots with a 2 peat : 1 hemlock bark : 1 perlite mix.

Microshoots also were rooted ex vitro. The bases of 30-to 40-mm-long shoots were dipped in 0,1 , or $5 \mathrm{~mm}$ IBA solution (dissolved in a small amount of $95 \%$ ethanol then brought to final volume with deionized water) for $1 \mathrm{~min}$ and planted in plastic pots as previously described. All rooting and acclimatization experiments had 14 shoots per treatment and were performed twice. Data were collected after 4 weeks.

Statistical analysis. Multiplication experiments were done as randomized completeblock designs, tested with analysis of variance and means separation by $t$ test. Because of the limited amount of plant material available (resulting in a small number of explants), initiation, rooting, and acclimatization data were analyzed using Fischer's exact test, which uses the exact $P$ value rather than an approximation.

\section{Results and Discussion}

Culture establishment. The initial responses of explants included tissue browning, microbial contamination (bacteria and fungi), bud growth, or no response. Tissue browning and explant contamination were evident after 5 to 7 days of culture. Tissue browning was confined to the plant tissue and did not stain the medium. Healthy explants started to show budbreak and elongation (bud growth) in 7 to 10 days, and new shoots ( 20 to $50 \mathrm{~mm}$ ) were excised and subcultured after 4 weeks. 'Barcelona' and 'Gassaway' each had 7\% to $60 \%$ of explants that did not show contamination, tissue browning, or bud growth during 4 weeks of culture (no response).

For 'Barcelona', grafted greenhouse-grown plants produced more growing explants from collections in March (67\%) and May (47\%) than several other combinations of cultivar and collection time (Table 1). Generally, growth from suckers was less, but for July explants it was not statistically different from grafted plants. The response for 'Gasaway' was similar to that of 'Barcelona', with better growth from March (87\%) and July (60\%) explants from grafted plants and July explants from suckers $(60 \%)$. In further tests of initiation from grafted greenhouse-grown plants of other cultivars, there was significantly more growth from explants taken in March than in July for 'Dundee' and more from March and May explants for 'Newberg', but there were no differences among collection dates with 'Willamette' (Table 2). To our knowledge, grafting has not been used previously as a pretreatment method for hazelnut tissue culture. These results indicate that grafting is a reliable method for improving the number of growing explants.

Suckers proved to be a useful explant source in July, but establishment rates in June and September were low. This difference may be related to high rainfall in June, contributing to more contaminants and the onset of dormancy in September. Explants from upper branches in all seasons had the least growth of explants from any source. When explants from forced outgrowth of upper branches of field-grown 'Gasaway' trees were used, the percentage of growing explants (19\%) was the same as those taken directly from upper branches. These results are similar to those of Diaz-Sala et al. (1990). In that study, $80 \%$ of single buds of forced mature branches (without additional cold treatment) of 'Tonda Gentile delle Langhe' hazelnut failed to respond, and the remaining $20 \%$ showed only leaf expansion and slight shoot elongation and did not develop further.

Nodal segments responded better than did shoot tips. Shoot tips initially showed leaf expansion, but all tips soon died without fur-

Table 1. Effects of explant source, collecting month, and genotype on the growth of hazelnut explants after 4 weeks of culture on NCGR-COR medium with $22.2 \mu \mathrm{M}$ BA and 0.04 $\mu \mathrm{M}$ IAA $(\mathrm{n}=15)$.

\begin{tabular}{llcc}
\hline & & \multicolumn{2}{c}{ No. explants growing } \\
\cline { 3 - 4 } Explant & Explanting & \multicolumn{2}{c}{ Genotype } \\
\cline { 3 - 4 } source & month & Barcelona & Gasaway \\
\hline Grafts & March & $10 \mathrm{a}$ & $13 \mathrm{a}$ \\
& May & $7 \mathrm{ab}$ & $4 \mathrm{bc}$ \\
& July & $4 \mathrm{a}-\mathrm{d}$ & $8 \mathrm{ab}$ \\
Upper & & & \\
branches & May & $1 \mathrm{~cd}$ & $1 \mathrm{c}$ \\
& June & $0 \mathrm{~d}$ & $1 \mathrm{c}$ \\
Suckers & August & $0 \mathrm{~d}$ & $0 \mathrm{c}$ \\
& June & $2 \mathrm{~b}-\mathrm{d}$ & $1 \mathrm{c}$ \\
& July & $5 \mathrm{a}-\mathrm{c}$ & $8 \mathrm{ab}$ \\
& September & $1 \mathrm{~cd}$ & $0 \mathrm{c}$ \\
\hline
\end{tabular}

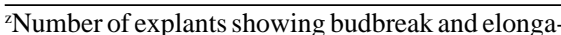
tion without contamination. Treatments with the same letter in a column are not significantly different at $P=0.05$ based on Fischer's exact test.

Table 2. Effects of genotype and explant collecting month on the growth of hazelnut explants from grafted greenhouse-grown plants after 4 weeks of culture on NCGR-COR medium with $22.2 \mu \mathrm{M}$ BA and $0.04 \mu \mathrm{M}$ IAA $(n=15)$.

\begin{tabular}{lccc}
\hline & \multicolumn{3}{c}{ No. explants initiating growth } \\
\cline { 2 - 4 } Explanting & \multicolumn{3}{c}{ Genotype } \\
\cline { 2 - 4 } month & Dundee & Newberg & Willamette \\
\hline March & $10 \mathrm{a}$ & $15 \mathrm{a}$ & 13 \\
May & $4 \mathrm{ab}$ & $14 \mathrm{a}$ & 8 \\
July & $3 \mathrm{~b}$ & $6 \mathrm{~b}$ & 7 \\
Significance & $*$ & $*$ & NS
\end{tabular}

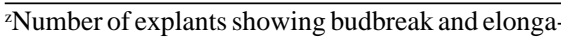
tion without contamination. Mean separation within columns at $P=0.05$ based on Fischer's exact test (* $=$ significant; NS $=$ nonsignificant). 
ther development. This failure also was noted with shoot tips of forced shoots (data not shown) and by Messeguer and Mele (1987) with 'Negret', probably because of physiological differences between shoot tips and nodal segments.

Like some other woody plants, tissue browning in hazelnut is a serious problem during culture establishment. Several approaches have been used to deal with this tissue browning (Preece and Compton, 1991). In our study, treatment of explants from fieldgrown trees with ascorbic acid, cysteine, 8HQS, DIECA, or $\mathrm{K}_{2} \mathrm{~S}_{2} \mathrm{O}_{7}$ solutions did not decrease tissue oxidation, i.e., browning (data not shown). Using explants from grafted plants was the best method for avoiding losses of all types, including tissue browning.

Paper chromatography indicated that tissues from field-grown trees generally had more phenolic compounds than tissues from grafted greenhouse-grown plants and shoot tips more than nodal segments. The levels were not quantified further than observation of chromatograms. These results substantiate our observations from in vitro culture establishment. A similar relationship was noted with nodal segments and shoot tips. Yu and Meredith (1986) reported that axillary shoots of grape (Vitis vinifera L.) had greater survival and lower endogenous phenolic concentrations than terminal shoots.

Based on these results, we conclude that the best explant sources were grafted greenhouse-grown plants. Suckers collected in July were the best option for field material collection for culture establishment. Stock (mother) plants in the greenhouse were used to decrease hazelnut tissue contamination (Messeguer and Mele, 1983), and juvenile materials had a better growth response and less oxidation than mature materials in conifers (Kurz, 1986). Our results show that grafted greenhouse-grown hazelnut plants may be rejuvenated or reinvigorated and provide an excellent explant source available within 2 months of grafting. Messeguer and Mele (1983) also found that the collecting season influenced explant response, but their best results (63\% of explants sprouted) with self-rooted, greenhouse-grown 'Negret' plants were those collected in the autumn. The differences between our results and Messeguer and Mele's may reflect differences in genotype and between grafted and self-rooted plants.

Shoot multiplication. The three new hazelnut cultivars tested responded similarly to 'Nonpareil' and 'Tonda Gentile Romana' ( $C$. avellana) in our previous study ( $\mathrm{Yu}$ and Reed, 1993). All three cultivars cultured on medium with $22.2 \mu \mathrm{M}$ BA produced significantly $(P \leq$ $0.05)$ fewer $(1 \mathrm{shoot})$ and shorter $(1 \mathrm{~cm})$ shoots than those cultured on medium containing any of the other growth regulator combinations (1.4 or 1.5 shoots). Shoots produced on medium with the (in $\mu \mathrm{M}) 6.7 \mathrm{BA}-0.04$ IBA combination were not significantly longer $(1.6 \mathrm{~cm})$ than those on $6.7 \mu \mathrm{M}$ BA alone $(1.4 \mathrm{~cm})$, but they were significantly longer than the BA$2 \mathrm{iP}$ combination $(1.3 \mathrm{~cm})$. The $($ in $\mu \mathrm{M}) 6.7$ BA-0.04 IBA combination was used for shoot multiplication based on the slightly longer size and improved leaf color. After two to three subcultures on this medium, single shoots were cut into shoot tip and nodal segments with single buds (explants), and each explant produced one to two new shoots (Fig. 1A). Of the two shoots produced, one was usually 2 to $4 \mathrm{~cm}$ long and was divided into three new explants; the other ( 5 to $10 \mathrm{~mm}$ ) produced one or two new explants, resulting in a total of three to five new explants per original explant in 4 weeks. All three cultivars produced a similar number of shoots, but 'Dundee' shoots were significantly longer than those of 'Willamette'. 'Newberg' shoots were intermediate in length.

Root induction and acclimatization. In vitro rooting frequency differed among the three cultivars. After 4 weeks, the rooting frequencies were $64 \%$ for 'Willamette', $78 \%$ for 'Newberg', and $100 \%$ for 'Dundee'. More than four 2- to 5-cm-long roots were obtained per rooted shoot for each of the three cultivars. Rooted and nonrooted shoots were transplanted to the greenhouse without further treatment, and all of them rooted and survived after 4 weeks of acclimatization.

Because a high survival rate was achieved after acclimatization for rooted and nonrooted shoots, we tested ex vitro root induction and acclimatization. Ex vitro rooting occurred in 2 to 3 weeks, and high rooting frequencies $(64 \%$ to $100 \%$ ) were obtained when shoots were dipped in 1 or 5 mm IBA solution (Table 3).
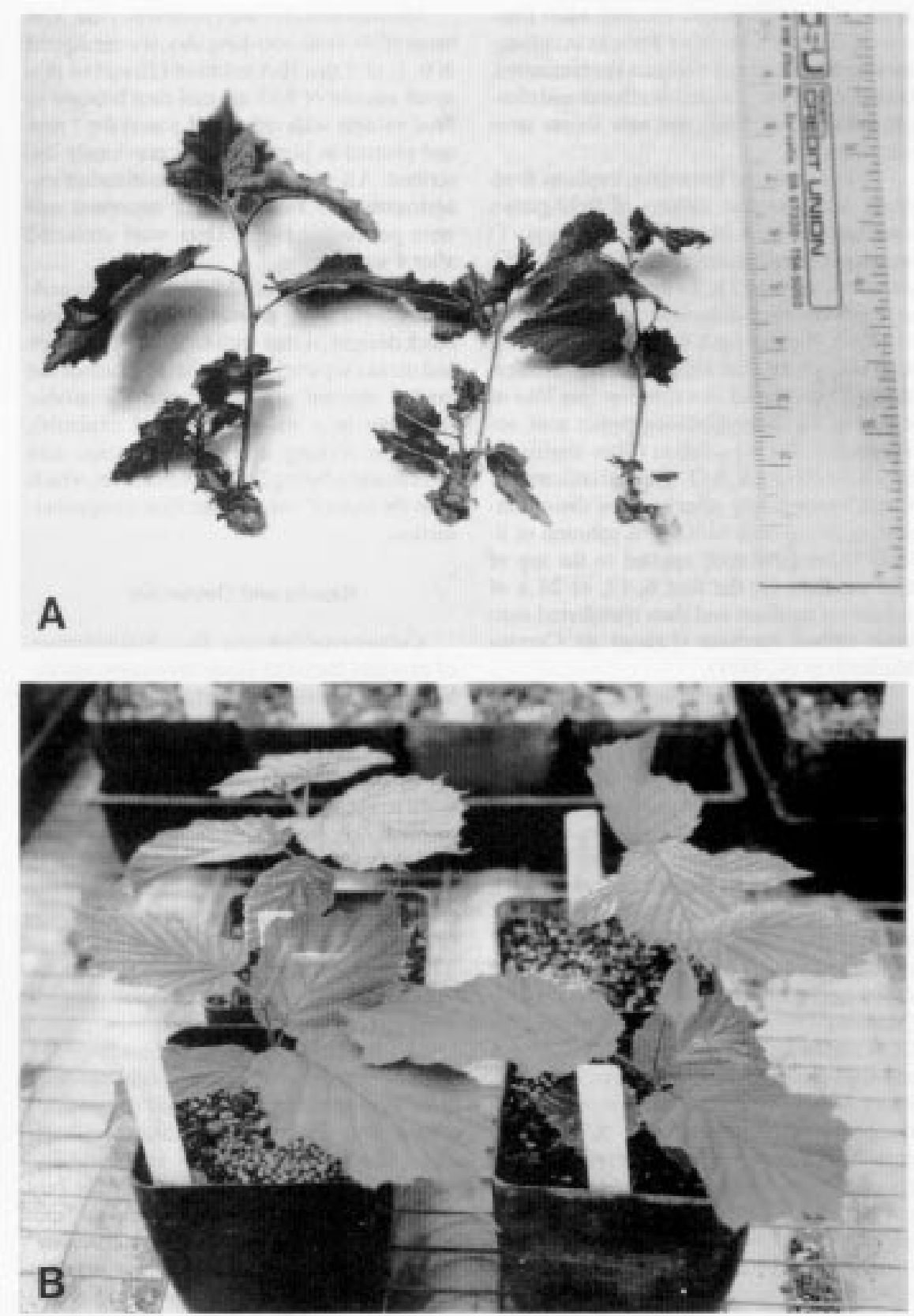

Fig. 1. (A) Shoot multiplication of 'Dundee' hazelnut rootstock after 4 weeks on NCGR-COR medium with $6.7 \mu \mathrm{M}$ BA and $0.04 \mu \mathrm{m}$ IBA. (B) 'Willamette' hazelnut plantlets established in the greenhouse via ex vitro rooting (by dipping into $1 \mathrm{~mm} I B A$ for $1 \mathrm{~min}$ ) and acclimating for 2 months. 
More ( 5 to 10 roots per shoot) and shorter ( 1 to $3 \mathrm{~cm}$ long) roots were produced with $5 \mathrm{~mm}$ than with 1 mM IBA $(\approx 5$ roots per shoot; 2 to $5 \mathrm{~cm}$ long). Shoots dipped in water ( $0 \mathrm{~mm} \mathrm{IBA})$ required a longer time to produce roots $(\approx 6$ weeks) and had a lower rooting frequency (36\% to $93 \%$ ) and fewer roots than shoots dipped in the IBA solutions. 'Dundee' and 'Willamette' rooted better than 'Newberg' in all treatments.

For in vitro and ex vitro rooting studies, plants were transplanted after loosening the lids of Magenta GA7 boxes in the culture room for 2 days. This step was required for successful acclimatization. High survival rates $(78 \%$ to $100 \%$ ) were achieved for in vitro and ex vitro root induction of all three cultivars, but fewer 'Newberg' shoots treated with $5 \mathrm{~mm}$ IBA survived than the other two similarly treated cultivars, and 'Newberg' shoots treated with the 5-mm IBA dip did not survive as well as the control (Table 3). Hazelnuts may develop dormancy after greenhouse establishment and may require a period of low temperature to break dormancy. Dormancy occurred in initial acclimatization trials but not in our experiments and does not affect survival. The plantlets grew well once they rooted (Fig. 1B). Because in vitro rooting is a time- and laborconsuming process, we suggest using ex vitro rooting.

\section{Conclusions}

A complete micropropagation system for hazelnut was achieved by selecting explants (nodal axillary segments) from shoots of grafted greenhouse-grown plants in March, May, or July or suckers of field-grown trees in July. Growth of $46 \%$ to $80 \%$ of explants from March through July compares favorably with the $38 \%$ spring and 10\% summer explant growth reported by Messeguer and Mele (1983). NCGR-COR medium with $22.2 \mu \mathrm{M}$ BA and $0.04 \mu \mathrm{M}$ indole-3-acetic acid (IAA) was used for culture establishment and $6.7 \mu \mathrm{M}$ BA and $0.04 \mu \mathrm{M}$ IBA for shoot multiplication. The three to five new explants produced each 4 weeks on this multiplication medium were about double the number reported in earlier studies (Bassil et al., 1992; Diaz-Sala et al., 1990). High frequencies of rooting were induced either in vitro on medium with $4.9 \mu \mathrm{M}$ IBA or ex vitro by dipping in 1 or $5 \mathrm{~mm} \mathrm{IBA} \mathrm{for}$ $1 \mathrm{~min}$. In vitro rooting of hazelnut has been reported previously (Bassil et al., 1992; DiazSala et al., 1990; Perez et al., 1987); however, our study demonstrated using ex vitro rooting. Using ex vitro rooting could improve the speed of transfer from the growth room to the greenhouse in commercial nurseries. Survival at $78 \%$ to $100 \%$ during acclimatization was achieved by growing plants in a 1 vermiculite $: 1$ perlite mixture under mist for 2 to 3 weeks and then transferring to the greenhouse bench.

\section{Literature Cited}

Abo El-Nil, M.M. 1982. Method for asexual reproduction of coniferous trees. U.S. Patent 4,353,184.

Bassil, N., D.W.S. Mok, M.C. Mok, and B.J. Rebhuhn. 1992. Micropropagation of the hazelnut, Corylus avellana. Acta Hort. 300:137-140.

Bonga, J.M. 1987. Clonal propagation of mature trees: Problems and possible solutions, p. 249271. In: J.M. Bonga and D.J. Durzan (eds.). Cell and tissue culture in forestry. Martinus Nijhoff, Dordrecht, The Netherlands.

Diaz-Sala, C., M. Rey, and R. Rodriquez. 1990. In vitro establishment of a cycloclonal chain from nodal segments and apical buds of adult hazel (Corylus avellana L.). Plant Cell Tissue Organ Cult. 23:151-157.

Driver, J.A. and A.H. Kuniyuki. 1984. In vitro propagation of Paradox walnut rootstock. HortScience 19:507-509.

Table 3. The effects of ex vitro rooting treatments on root induction and the survival of transplanted hazelnut plantlets after 4 weeks of rooting and acclimating in the greenhouse $(n=28)$.

\begin{tabular}{|c|c|c|c|c|c|c|}
\hline \multirow[b]{4}{*}{ BA (mM) } & \multicolumn{6}{|c|}{ No. plantlets } \\
\hline & \multicolumn{3}{|c|}{ Rooted } & \multicolumn{3}{|c|}{ Surviving acclimatization } \\
\hline & \multicolumn{3}{|c|}{ Genotype } & \multicolumn{3}{|c|}{ Genotype } \\
\hline & Newberg $^{2}$ & Dundee & Willamette & Newberg & Dundee & Willamette \\
\hline 0 & $10 \mathrm{~b}$ & $18 \mathrm{~b}$ & 26 & $28 \mathrm{a}$ & 28 & 28 \\
\hline 1 & $22 \mathrm{a}$ & $26 \mathrm{a}$ & 28 & $26 \mathrm{ab}$ & 28 & 28 \\
\hline 5 & $18 \mathrm{ab}$ & $26 a$ & 24 & $22 \mathrm{~b}$ & 28 & 28 \\
\hline Significance & $*$ & $*$ & NS & $*$ & NS & NS \\
\hline
\end{tabular}

${ }^{2}$ Mean separation within columns at $P=0.05$ based on Fischer's exact test $(*=$ significant; NS $=$ nonsignificant).
Franclet, A., et al. 1987. Rejuvenation, p. 232-248. In: J.M. Bonga and D.J. Durzan (eds.). Cell and tissue culture in forestry. vol. 1. Martinus Nijhoffm, Dordrecht, The Netherlands.

Kurz, M.L. 1986. Tissue culture of conifers. Combined Proc. Intl. Plant Prop. Soc. 35:206-216.

Lagerstedt, H.B. 1990. Filbert rootstock and cultivar introductions in Oregon. Northern Nut Growers Assn. Annu. Rpt. 1990 81:60-63.

Lagerstedt, H.B. 1993. 'Newberg' and 'Dundee', two new filbert rootstocks. Nut Growers Soc. Oregon, Washington, and British Columbia Proc. 78th Annu. Mtg. 78:94-101.

Laimer da Camara Machado, M.L., et al. 1991. A new, efficient method using 8-hydroxyquinolinol-sulfate for the initiation and establishment of tissue cultures of apple from adult material. Plant Cell Tissue Organ Cult. 27:155160.

Mehlenbacher, S.A., A.N. Miller, M.M. Thompson, H.B. Lagerstedt, and D. Smith. 1991a. 'Willamette' hazelnut. HortScience 26:13411342.

Mehlenbacher, S.A., M.M. Thompson, and H.R. Cameron. 1991b. Occurrence and inheritance of resistance to eastern filbert blight in 'Gasaway' hazelnut. HortScience 26:410-411.

Messeguer, J. and E. Mele. 1983. Clonal propagation of Corylus avellana L. "in vitro," p. 293 295. Atti del Convegno Internazionale sul Nocciuolo, Avellino, Italy, 22-24 Sept. 1983.

Messeguer, J. and E. Mele. 1987. In vitro propagation of adult material and seedlings of Corylus avellana. Acta Hort. 212:499-503.

Oydvin, J. and D.G. Richardson. 1987. A paper chromatographic survey of the phenol content of apple peel from scab resistant and scab susceptible genotypes. Norw. J. Agr. Sci. 1:7-13.

Perez, C., A. Rodriguez, A. Revilla, R. Rodriguez, and R.S. Tames. 1987. Filbert plantlet formation “in vitro" culture. Acta Hort. 212:505-509.

Preece, J.E. and M.E. Compton. 1991. Problems with explant exudation in micropropagation, $\mathrm{p}$. 168-189. In: Y.P.S. Bajaj (ed.). Biotechnology in agriculture and forestry. vol. 17. High-tech and micropropagation I. Springer-Verlag, Berlin, Heidelberg.

Thorpe, T.A. and I.S. Harry. 1990. Special problems and prospects in the propagation of woody species, p. 67-74. In: R. Rodriguez, R. SanchezTames, and D. Durzan (eds.). Plant aging: Basic and applied approaches. Plenum Press, New York.

Yu, D-H. and C.P. Meredith. 1986. The influence of explant origin on tissue browning and shoot production in shoot tip cultures of grapevine. $\mathrm{J}$. Amer. Soc. Hort. Sci. 111:972-975.

Yu, X. and B.M. Reed. 1993. Improved shoot multiplication of mature hazelnut (Corylus avellana L.) in vitro using glucose as a carbon source. Plant Cell Rpt. 12:256-259. 